\title{
DIE GRÜJVEY:
}

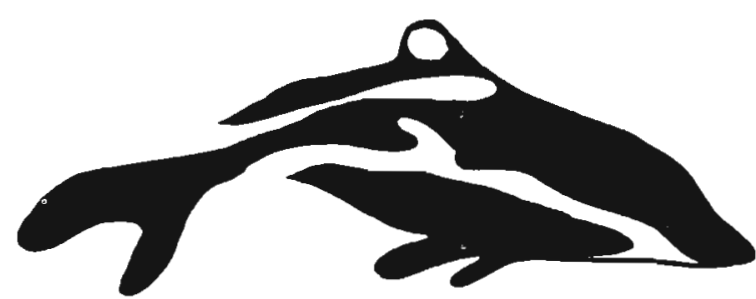

\section{Protection of Nature}

and the

Countryside

\begin{abstract}
The planning of space is not only necessary for industry, but also, in the future, for the conservation of larger nature preserves. These preserves not only serve humans, but are also important for the preservation of plant and animal species which would otherwise be subject to certaın extinction. If a nature preserve has lost its actual protective function, it should be restored to its original state through appropriate measures. Up until now environmental protection, which oniy preserves indi vidual species or designated areas from industrial destruction, is completely inadequate. Environment protection should be practised not only in these isolated regions, but also and importantly where human beings ive: in villages and clties and their surrqundings.
\end{abstract}

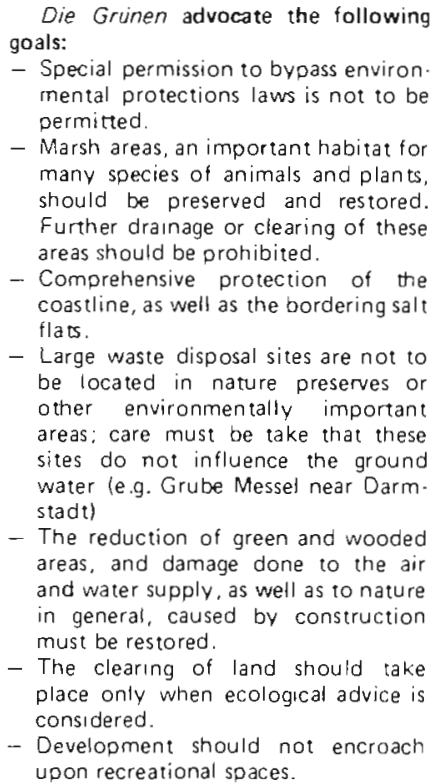
goals:

- Special permission to bypass environ. mental protections laws is not to be permined.

- Marsh areas, an important habitat for many species of animals and plants, should be preserved and restored. Further drainage or clearing of these areas should be orohibited.

- Comprehensive protection of the coastline, as well as the bordering salt flats.

- Large waste disposal sites are not to be located in nature preserves or other environmentally important areas: care must be take that these sites do not influence the ground water (e.g. Grube Messel near Darm. stadt)

The reduction of green and wooded areas, and damage done to the air and water supply, as well as to nature in general, caused by construction must be restored.

- The clearing of land should take place only when ecological advice is considered.

- Development should not encroach upon recreational spaces.

\begin{abstract}
- The inclusion of protected zones e.g. parks, green areas, lakes, springs or pouds) is obligatory in community development planning.

- Ecological consideratıons speak against new large transportation projects such as large airports, canals. and highways.

- Environmental protection agencies and officies (including a federal environmental ministry) with qualified personnel (conservationists) and appropriate technical facilities. should supervise and advise at the local and federal level

- Environmental protection organiza. tuons, as well as concerned citizen groups are to have a say in area planning and should have the right to sue.

- We demand the instifution of "open planning" and that the entiredecision-making process be made puolic.

- Environmental exoerts from associa. lions and citizen groups have a right to participate in the planning processes.
\end{abstract}

\section{Animal and Plant World (Protection of Species)}

As a result of unrestrained human interference, an increasing number of plant and animal species is being exterminated; the number of species has been reduced, and the ecological balance in nature is being destroyed more and more.

\section{DIE GRUNEN demand:}

- The preservation and restoration of primitive regions and the reintroduction of extinct plant and animal species.

- The protection of indigenous animals and plants in their natural environment must take precedence over economic development. The natural environment of animals and plants must be guaranteed by a comprehensive system of biotope protection; the Federal Republic should support at the international level the protection of species, e.g., by supporting a in Italy, and protesting against the commercial hunung of whales.

Trade involving enoangered plant and animal species, and the products of these species must be prohibited. As licensing for such products le.g. furs) and the prohibition of the import and sale of seal skins. Greater protection of birds from hunting. and the destruction of biozides, and biotopes

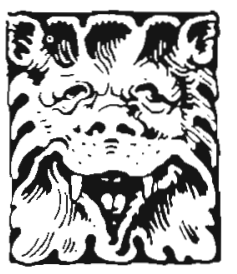


- Chemical pest control should be replaced by biolocical methods. As an emergency measure. protection bureaus are to regulate the use of herbicides and insecticides: only those substances are to be used which do not affect the ecosystem for more than one year.

- Stronger protective measures for trees are necessary, especially in cities, but in the country as well Salting of streets and roads must be In the clearing of land and construc tion planning small bushes and hedges must be preserved or replanted

A list of existing plant and animal species should be established in order to determine how healthy and exten. sive these species are.

- Environmental protection agencies should have greater authority. Qualified ecologists and conservation ists should supervise the species composition of a region lbiotope mapping) .

- Crearion of large unsettled nature preserves, economic use of this land may only be permitted when it is necessary for the preservation of this land

\section{Wildlife Protection}

Industrial methods for the breeding of livestock and poultry violate present anımal protection laws, and have led to increased mistreatment of animals: mass breeding of cnickens and fur-bearıng anrmals, and the forced fattening of calves and pigs are all instances of such practices.

Thousends of animals are killed daily in scientific experiments, e.g. in animal experiments testing chemicals. weapons, pharmaceuticals, and cosmetics.

Die Grünen advocate the following goals:

- Animals should no longer legally be considered "things", but should recerve a special legal status. Cruelty to animals must be severly punished.

- Domestic agricultural animals should be kept in natural conditions corresponding to their species type.

- Cruelty to animals resulting from mass animal husbandry practices should finally be abolished. As an immediate measure we demand that a law be passed requiring the state ment of information concerning the origin of animal products, both domestic or imported le.g. whether the chickens were kept in cages or were left free to roam?.

- Keeping animals in accordance with the needs of their species is also in the self-interest of agriculture. This is especially true for smalter farms. since they are trequently forced out of business by competition from mass-industrialized animal produc. tion.

- Strict rules guaranteeing a natural habitat for animals should also apply to household pets, and are to he officially supervised by experts. Private and public wildlife preserves are to be regulated in a similar manner.

- Rules for the transport of animals. including slaughterhouse animals. with stronger consideration given to animal protection.

- In place of animal experiments we demand proven and feasible alterna. tives (e.g., experiments with cell cultures or with computer simulation in the area of organic medicinel.

- There must be a balancing of legal claims between the use expected from animals and the animal's right to life. Even psychological resarch using animals is highly questionable.

The sensless repetition of experiments with animals should be avoided by an obligation to publish results and by the establishment of a centralized agency for the supervisıon of ail authorized animals experiments.

- We reject genetic engıneering in animals and humans.

We will guarantee that the responsibility for protecting animals and plants is transferred from the agriculture munistry to an environmentalministry.
Admirers of George Abbe's writing may look forward to publication, beginning in the Summer Issue of BETWEEN THE SPECIES

of portions of Abbe's novel,

To Perish Never.

Plans are to follow this with serialization of Negavit.

\section{B}

BETWEEN THE SPECIES welcomes letters, which we will on occasion publish, from readers.

Please limic to 500 words in length.

If response warrants, an adjunct newsletter, for discussion, authored entirely by readers and letter writers, will be initiated. 